\title{
ARTIKKELIT
}

\section{ע Millaisia tavoitteita iäkäs kotihoidon tai ympärivuorokautisen hoidon asiakas asettaa hoidolleen?}

\author{
Kim Josefsson ${ }^{1}$, Matti Mäkelä ${ }^{1}$, Aleksandr Gerasin ${ }^{1}$, Outi Ranta ${ }^{1}$, \\ Satu Havulinna ${ }^{1}$, Anja Noro ${ }^{1}$ \\ ${ }^{1}$ Terveyden ja hyvinvoinnin laitos (THL), Hyvinvointi-osasto, \\ Iäkkäät, vammaiset ja toimintakyky -yksikkö
}

\begin{abstract}
Tässä tutkimuksessa selvitettiin kotihoidon ja ympärivuorokautisen hoidon asiakkaiden tavoitteita omalle hoidolleen. Lisäksi selvitettiin, miten tavoitteiden määrä oli yhteydessä asiakkaan kognitiiviseen suoriutumiseen. Vastaukset tavoitteisiin saatiin osana asiakkaan RAI-arviointia. Tutkimusaineistoon kuului 1101 kotihoidon lomakkeella arvioitua asiakasta ja 509 ympärivuorokautisen hoidon lomakkeella arvioitua asiakasta. Ympärivuorokautisen hoidon asiakkaat olivat arkitoiminnoista suoriutumisen (ADL) ja kognition (CPS) perusteella toimintakyvyltään keskimäärin selkeästi heikompia kuin kotihoidon asiakkaat. Ympärivuorokautisen hoidon lomakkeella arvioiduista asiakkaista 31 prosenttia ei maininnut yhtäkään tavoitetta. Kotihoidon lomakkeella arvioiduilla asiakkailla vastaava osuus oli 15 prosenttia. Ympärivuorokautisen hoidon asiakkailla kuntoon (15\%) ja mielihyvää tuoviin asioihin (13\%) liittyvät tavoitteet olivat yleisimpiä. Kotihoidon asiakkailla arkiaskareiden sujuminen (24\%), kunnon paraneminen tai ylläpitäminen (22\%) ja asumisjärjestelyt (19\%) olivat muita tavoitteita yleisempiä. Vastausten määrä laski voimakkaasti kognition heikentyessä, mutta kaikilla kognition tasoilla oli tavoitteita. Iäkkäät asiakkaat asettivat hoidolleen konkreettisia tavoitteita, jos niitä tiedusteltiin systemaattisesti.
\end{abstract}

\section{Johdanto}

Asiakaslähtöisyydestä on tullut viime vuosina tärkeä teema vanhustenhuollossa ja koko palvelujärjestelmässä. WHO puoltaa asiakaslähtöistä hoidon suunnittelua (Coulter ym. 2015). Asiakaslähtöisyys on nostettu keskiöön vuosien 2017 ja 2020 hyvän ikääntymisen laa- tusuosituksissa (Sosiaali- ja terveysministeriö 2017; Sosiaali- ja terveysministeriö \& Suomen Kuntaliitto 2020) ja myös Sipilän hallituksen Kehitetään ikäihmisten kotihoitoa ja vahvistetaan kaikenikäisten omaishoitoa -kärkihankkeessa (Noro \& Karppanen 2019). Asiakaslähtöisyydellä tarkoitetaan mahdollisuutta vaikuttaa oman elämänsä kulkuun, mah- 
dollisuuksiin, toimintoihin, palveluihin ja yhteisiin asioihin (Isola ym. 2017). Toisin sanoen asiakaslähtöisessä vanhuspalvelun toteutuksessa iäkkään henkilön on oltava aidosti osallinen ja asiakkaan mielipidettä on kuultava palvelun toteutuksessa (Sosiaali- ja terveysministeriö \& Suomen Kuntaliitto 2020).

Asiakaslähtöisyys itsessään ei ole päämäärä vaan työskentelytapa varsinaiseen tavoitteeseen pääsemiseksi. Tämä tavoite on asiakkaan itsemääräämisoikeus. Asiakaslähtöisessä työtavassa palvelut räätälöidään yksilön arvojen ja tarpeiden mukaan niin, että asiakkaan itsemääräämisoikeus turvataan (Pirhonen 2017). Tällöin asiakas tunnustetaan yksilöksi ja hänet hyväksytään sellaisena kuin hän on. Kun päämääränä on itsemääräämisoikeus, asiakas nähdään aktiivisena toimijana, joka määrittelee itse parhaan kykynsä mukaan itselleen tärkeät ratkaistavat asiat. Tämä auttaa fokusoimaan hoidon niihin henkilökohtaisiin tavoitteisiin, jotka asiakas kokee tärkeiksi, eikä niihin tavoitteisiin, jotka hoitaja tai ammattihenkilö kokee tärkeiksi.

Henkilökohtaiset tavoitteet voidaan kiteyttää olosuhteiksi, joita kohti ihminen pyrkii tai joista hän haluaa pois (Freund \& Riediger 2006). Henkilökohtaiset tavoitteet ovat tärkeä motivaation lähde, sillä ihmiset ovat yleensä valmiita ponnistelemaan ja tekemään työtä saavuttaakseen ne (Deci \& Ryan 2000). Tavoitteita kohti ponnisteleminen ja niiden saavuttaminen lisäävät usein hyvinvointia, koska tavoitteiden vuoksi tehty työ ja siihen käytetty aika koetaan merkitykselliseksi (Little 2007).

Erilaisten toimintarajoitteiden vuoksi hoitajat ovat vanhuspalvelujen asiakkaille tärkeä tuki henkilökohtaisten hoitotavoitteiden saavuttamisessa. Tavoitteita kohti pyrkiminen voi lisätä asiakkaan hyvinvointia etenkin, jos tavoitteet ovat aidosti asiakkaan omia ja asiakkaalla on sisältäpäin kumpuava motivaatio niitä kohti pyrkimiseen (Deci \& Ryan 2000). Tutkimuksissa on tunnistettu tekijöitä, jotka tukevat tai vaikeuttavat hoitajien työtä asiakkaan omia tavoitteita kohti pyrkimisessä. Niistä tärkeimpien joukossa on tiivis ja toimiva yh- teistyö asiakkaan hoitoon osallistuvien ammattilaisten ja asiakkaan omaisten kesken niin, että vallitsee luottamuksen, ymmärryksen ja tiedon jakamisen ilmapiiri (McCormack \& McCance 2006; Elliott ym. 2016). Tarvitaan myös järjestelmällinen tapa kartoittaa asiakkaan tarpeita ja tavoitteita, sillä ne ovat asiakaslähtöisyyden perusta (Howard ym. 2016). Parhaassa tapauksessa asiakas osallistuu hoitonsa päätösprosessin eri vaiheiden työstämiseen ja pystyy näkemään ja ymmärtämään oman vaikutuksensa asioiden etenemiseen (Koivisto ym. 2018).

Asiakkaan yksilölliset tavoitteet huomioiva työtapa vaatii siihen osallistuvilta kykyä kuunteluun ja selkeään viestintään sekä hyviä neuvottelutaitoja ja joustavuutta sopeutua vaihteleviin tilanteisiin ja toiveisiin (Coulter \& Oldham 2016). Asiakkaan tilanne kattaa lääketieteellisten asioiden lisäksi paljon muutakin, esimerkiksi psykologiset, sosiaaliset ja hengelliset tarpeet ja odotukset (Howard ym. 2016). Asiakkaat kokevat erityisen tärkeäksi aidon välittämisen ja myötätunnon sekä kunnioituksen hoitohenkilökunnan taholta. Keskeisiksi haasteiksi asiakaslähtöisen työtavan toteutuksessa on koettu hoitajan liian vähäinen aika yhtä asiakasta kohden, liian vähäinen henkilöstö ja muut kiireet (Eaton ym. 2015; Coulter \& Oldham 2016; Moore ym. 2017). Monesti asiakkaat kokevat vievänsä kysymyksillään kiireisen hoitohenkilökunnan aikaa sen sijaan, että he kokisivat asiakkaan kuuntelemisen olevan henkilöstön sisäänrakennettu, itsestään selvä toimintatapa (Coulter \& Oldham 2016).

Osa asiakaslähtöisen yksilöllisen toiminnan haasteista kumpuaa asiakkaiden omista asenteista tai puutteelliseksi koetusta tiedosta. Moni asiakas sanoo ymmärtävänsä huonosti hoitoonsa liittyviä asioita, eikä kaikilla asiakkailla ole itseluottamusta tai jaksamista miettiä jokapäiväisen hoidon järjestämistä (Eaton ym. 2015). Lisäksi asiakkaat ovat usein tietämättömiä hoitovaihtoehdoista ja niiden seurauksista tai siitä, että valinnan mahdollisuuksia on ylipäätään olemassa (Lewis-Barned 2016; Bunn ym. 2018). Kyse voi olla myös kommunikaa- 
tion haasteista ja asiakkaan ymmärretyksi tulemisesta. Hoitajan ammattitaitoa on keskustella asiakkaan kanssa niin, että asiakkaan asettamat tavoitteet saadaan esiin ja kirjattua oikein. Asiakkaan heikentynyt kognitio tai psyykkinen hyvinvointi on huomioitava, sillä esimerkiksi psykoosissa oleva henkilö saattaa asettaa vaarallisia tai täysin epärealistisia tavoitteita (Moore ym. 2017). Joissakin tapauksissa voidaan törmätä asiakkaan ja hoitohenkilökunnan näkemyseroihin asiakkaan terveydentilasta ja yleisistä lähtökohdista, tai asiakkaan toiveet voivat poiketa yleisistä hoitosuosituksista (Bunn ym. 2018). Eräs järjestelmätason haaste on se, että asiakaslähtöisyyttä ja asiakkaan yksilöllisiä tavoitteita pidetään strategisena tavoitteena, mutta tavoitteen toteutumisesta ei välttämättä palkita eikä toteutumatta jäämisestä rangaista, mikä voi vähentää henkilöstön motivaatiota huolehtia asiakkaan tavoitteiden toteutumisesta kiireen keskellä (Bunn ym. 2018).

Vanhuspalvelujen asiakastasoisessa seurannassa Suomessa ei ole ollut käytössä järjestelmällistä menetelmää asiakkaan omien tavoitteiden kartoittamiseksi. Sinänsä tavoitteiden asettaminen on aina ollut kiinteä osa asiakastyötä. Vanhustyössä on erityisen tärkeää tunnustaa asiakkaan omien kokemusten, tuntemusten ja prioriteettien rooli, jotta asiakaskokemus olisi myönteinen. Siinä, missä toinen toivoo pystyvänsä vielä ylipäätään kävelemään, toinen toivoo pystyvänsä kävelemään yhden sijaan kaksi kilometrin pituista lenkkiä viikossa. Koska vanhuspalvelujen asiakkaat ovat toimintakyvyltään hyvin erilaisia, myös asetetut tavoitteet ja toiveet poikkeavat toisistaan paljon.

Aiempaa tutkimusta iäkkäiden asiakkaiden näkökulman ja toiveiden huomioimisesta on melko vähän (Bunn ym. 2018). Lisäksi suuri osa tutkimuksesta on tehty sairaalaympäristössä, jolloin sovellettavuus kotihoitoon ja tehostettuun palveluasumiseen on epävarmaa (Kogan ym. 2016). Ei ole olemassa kattavaa tietoa siitä, missä määrin kotihoidon ja tehostetun palveluasumisen asiakkaat asettavat omia tavoitteita. Aiempi suomalainen tutkimus on osoittanut, että sekä kognitiivisesti terveet että muistisairaat iäkkäät tehostetussa palveluasumisessa asettivat ryhmäprosessia koskevia tavoitteita (Jansson ym. 2021).

Erilaiset toimintakyvyn rajoitteet ovat yleisiä tehostetun palveluasumisen asiakkailla. Yhteiseurooppalaisen seitsemän EU-maata (ml. Suomi) kattavan tutkimuksen mukaan noin 80 prosenttia asiakkaista tarvitsi apua päivittäisissä toiminnoissa, kognitio oli heikentynyt noin kahdella kolmasosalla ja masennusoireita ja käyttäytymishäiriöitä oli usealla kymmenellä prosentilla asiakkaista (Onder ym. 2012). Kuusi Euroopan maata (ml. Suomi) kattavan tutkimuksen mukaan asiakkaiden toimintakyky oli parempi kotihoidossa kuin tehostetussa palveluasumisessa, mutta kotihoidossakin vain joka kolmannella asiakkaalla muistin toiminta ei ollut lainkaan heikentynyt ja vain noin joka viides oli täysin itsenäinen raha-asioiden hoidossa ja lääkkeiden ottamisessa (GarmsHomolová ym. 2017). Lisäksi noin 40 prosentilla kotihoidon asiakkaista sosiaaliset kontaktit rajoittuivat lähimpiin ystäviin ja sukulaisiin.

Tämän tutkimuksen tavoitteena on selvittää, millaisia tavoitteita kotihoidon ja tehostetun palveluasumisen asiakkaat asettavat hoidolleen ja miten näitä tavoitteita voidaan luokitella. Tavoitteiden kattavan laadullisen esittelyn sijaan pyrkimyksenä on muodostaa luokittelukehikko, jonka avulla yksittäisten asiakkaiden tavoitteita voidaan koota yhteen ja muodostaa määrällinen yleiskuva asiakkaiden tavoitteiden sisällöstä.

\section{Menetelmät ja tutkimusaineisto}

Tutkimuksessa käytettiin kansainvälisiä kotihoidon ja ympärivuorokautisen hoidon RAIarviointivälineitä. Lyhenne RAI tulee sanoista Resident Assessment Instrument, suomeksi "asukkaan arviointiväline" (InterRAI consortium 2020). RAI-järjestelmä on standardoitu tiedonkeruun ja havainnoinnin välineistö, joka on tarkoitettu asiakkaan palvelutarpeen ar- 
viointiin ja joka tuottaa tietoa hoito-, kuntoutus- ja palvelusuunnitelman laatimiseen. RAIarvioinneista saatavaa tietoa hyödynnetään myös suunniteltaessa ja seurattaessa asiakkaiden hoitoa ja palvelua sekä ylemmän tason johtamisessa.

Vuonna 2018 suomalaisiin kotihoidon ja ympärivuorokautisen hoidon RAI-välineisiin lisättiin kysymys asiakkaan omista tavoitteista hoidolle siinä toivossa, että asiakkaan tavoitteiden kirjaaminen vaikuttaisi palvelujen suunnitteluun. Kysymyksen lisääminen oli suomalaista edelläkävijyyttä. Myös uusimpiin RAIvälineiden kansainvälisiin versioihin on nyt lisätty kysymys asiakkaan hoidolleen asettamista omista tavoitteista.

Tutkimuksen aineisto poimittiin ensimmäisestä puolivuosittaisesta tiedonkeruusta asiakkaan omia tavoitteita koskevan kysymyksen lisäämisen jälkeen vuonna 2018. Mukaan otettiin kaikki arvioinnit, joissa asiakkaan tavoitteeksi oli kirjattu muu kuin tyhjä vastaus, esimerkiksi "asiakas ei ilmaise tavoitteita". Tutkimusaineisto koostui 1101 kotihoidon ja 509 ympärivuorokautisen hoidon lomakkeella arvioidusta asiakkaasta.

Taustatietoja tutkimusjoukosta on esitetty taulukossa 1. Asiakkaat olivat keskimäärin yli 80-vuotiaita, ja suurin osa oli naisia. Asiakkaita oli mukana yli 50 eri kunnasta. Mukana oli henkilöitä, joiden toimintakyky oli vain lievästi heikentynyt, ja asiakkaita, joiden toimintakyky oli heikentynyt paljon, kuten arkitoiminnoista suoriutumista ja kognitiota kuvaavista tunnusluvuista nähdään. Taulukossa 1 asiakkaat on luokiteltu palvelutyypin mukaan. Huomattakoon, että vanhuspalveluiden järjestäjä on saanut itse päättää, kumpaa RAIvälinettä (kotihoidon väline vai ympärivuorokautisen hoidon väline) yksiköissään käyttää. Tämä on perusteltua, koska saman palvelutyypin sisällä on paljon vaihtelua asiakkaiden toimintakyvyssä ja toimintatavoissa riippuen yksiköstä, ja RAI-välineet on tarkoitettu käytännön asiakastyön ja johtamisen tueksi. Ympärivuorokautisen hoidon välineellä ar- vioidut asiakkaat sijoittuvat tehostettuun palveluasumiseen, vanhainkoteihin tai vuodeosastoille. Myös kotihoidon välineellä arvioiduista 304 palveluasumisen asukkaasta valtaosa on tehostetun palveluasumisen piirissä. Näistä yli 200 on Helsingin kaupungin asiakkaita, koska Helsinki on arvioinut kotihoidon RAIvälineen sopivan parhaiten moniin kaupungin tehostetun palveluasumisen yksiköihin. Tavallisen palveluasumisen asiakkaita on siis aineistossa vain vähän.

\section{Asiakkaan ilmaisemat palvelun tai} hoidon tavoitteet RAI-välineissä

Jokainen RAI-väline on kokonaisuus, johon sisältyy ohjeistus arvioinnin tekemiseen ja työvälineitä arviointitiedon hyödyntämiseksi (Terveyden ja hyvinvoinnin laitos 2019). Arviointilomakkeessa on kysymykset vastausvaihtoehtoineen. Käsikirja sisältää RAI-arvioinnin periaatteet, arviointiohjeistuksen sekä ohjeita arviointitiedon käyttöön. Asiakkaista kerätyt tiedot tallennetaan asiakas-/potilastietojärjestelmään. Hoitajilla on peruskoulutuksen lisäksi käytössään sähköinen ohjelmistoon sisältyvä käsikirja. Kattavaa lisätietoa RAI-järjestelmästä löytyy Terveyden ja hyvinvoinnin laitoksen verkkokoulusta (Terveyden ja hyvinvoinnin laitos 2021).

RAI-käsikirjassa tavoitteista ohjeistetaan kysymään mahdollisimman yleisellä tasolla. Käsikirja ohjeistaa kirjaamaan vain ne tavoitteet, jot$\mathrm{ka}$ asiakas itse tuo esiin. Esimerkiksi murtuneen käden kuntoutus on hoidollinen tavoite, mutta se ei ole asiakkaan oma tavoite, jos asiakas ei itse sitä mainitse. Mahdollisina apukysymyksinä kehotetaan kokeilemaan muun muassa seuraavia: "Millaista apua toivot meiltä?" "Miten toivot hyötyväsi täällä olostasi?" "Onko sinulla jokin asia, johon toivot muutosta?"Jokainen tavoite ohjeistetaan kirjaamaan omalle rivilleen, eikä tavoitteiden määrää ole rajoitettu. Mikäli asiakas ei pysty kommunikoimaan tai ei vastaa varsinaiseen kysymykseen, ohjeistetaan kirjaamaan:"asiakas ei ilmaise tavoitteita". 
Taulukko 1. Taustatietoja tutkimusjoukosta.

\begin{tabular}{|c|c|c|}
\hline & $\begin{array}{l}\text { Kotihoidon välineellä } \\
\text { arvioidut asiakkaat }\end{array}$ & $\begin{array}{l}\text { Ympärivuorokautisen } \\
\text { hoidon välineellä } \\
\text { arvioidut asiakkaat }\end{array}$ \\
\hline & $\mathrm{n}(\%)$ & $\mathrm{n}(\%)$ \\
\hline Arvioituja asiakkaita & 1101 & 509 \\
\hline Naisten prosenttiosuus & 68.6 & 72.3 \\
\hline Kotihoidon asiakkaat & $796(72.3)$ & o \\
\hline $\begin{array}{l}\text { Asiakkaat tehostetussa ja tavallisessa } \\
\text { palveluasumisessa }\end{array}$ & $304(27.6)$ & $392(77.0)$ \\
\hline Vanhainkotien asiakkaat & $1(0.1)$ & $93(18.3)$ \\
\hline Asiakkaita vuodeosastoilla & o & $24(4.7)$ \\
\hline Asiakkaiden vastauksia kirjattu yhteensä & 1475 & 640 \\
\hline Yksi vastaus & $843(76.6)$ & $423(83.1)$ \\
\hline Kaksi vastausta & $180(16.4)$ & $56(11.0)$ \\
\hline Kolme vastausta & $55(5.0)$ & $21(4.1)$ \\
\hline Neljä vastausta & $14(1.3)$ & $7(1.4)$ \\
\hline Viisi vastausta & $6(0.5)$ & $1(0.2)$ \\
\hline Enemmän kuin viisi vastausta & $3(0.3)$ & $1(0.2)$ \\
\hline \multicolumn{3}{|l|}{ Asiakkaiden hallinnollinen jakautuminen } \\
\hline Kuntia & 52 & 47 \\
\hline Hoitoyksiköitä & 329 & 214 \\
\hline Organisaatioita & $\begin{array}{l}47 \\
\mathrm{KA}(\mathrm{KH})\end{array}$ & $\begin{array}{l}55 \\
\text { KA (KH) }\end{array}$ \\
\hline lkä & $81.2(10.0)$ & $84.4(8.4)$ \\
\hline Arkitoiminnot (ADL) & $1.3(1.7)$ & $3.5(1.7)$ \\
\hline Arkitoiminnot (IADL) & $3.6(2.0)$ & ei käytössä \\
\hline Kognitio (CPS) & $1.7(1.3)$ & $2.9(1.5)$ \\
\hline
\end{tabular}

$\mathrm{KA}=$ keskiarvo, $\mathrm{KH}$ = keskihajonta, $\mathrm{ADL}=$ Activities of Daily Living (asteikko o-6, o=itsenäinen 6=täysin autettava), IADL = Instrumental Activities of Daily Living (asteikko o-6, o=ei vaikeuksia 6=paljon vaikeuksia), CPS = Cognitive Performance Scale (asteikko o-6, o=ei häiriötä 6=kognition erittäin vaikea heikkeneminen).

\section{Vastausten analysointi}

Taulukossa 1 puhutaan asiakkaan vastauksista ja myöhemmin taulukossa 2 asiakkaan tavoitteista. Näillä on laadullinen ero. Vastaus viittaa hoitajan tietojärjestelmään tallentamaan yhteen riviin, kun taas tavoite viittaa vastauksista tässä tutkimuksessa lukemisen jälkeen tunnistettuihin yksittäisiin tavoitteisiin. Vaikka käsikirjassa ohjeistettiin kirjaamaan jokainen erillinen tavoite omalle rivilleen, tätä kehotusta ei ollut aina noudatettu. Käytännössä asiakkaiden vastaukset saattoivat olla niin sanottuja kompleksivastauksia: yksi vastaus yhdellä vastausrivillä saattoi sisältää monta erillistä tavoitetta, esimerkiksi" haluaisin pysyä kunnossa, keittää itse kahvia ja tavata enemmän ihmisiä". Edellä mainittu vastaus sisälsi kolme tavoitetta (kunto, kahvi, ihmisten tapaaminen). Vastaus ei sisältänyt lainkaan tavoitteita, mikäli oli kirjattu "asiakas ei pysty ilmaisemaan tavoitteita" tai muuta vastaavaa.

\section{Tavoiteluokkien määrittely}

Määrällistä analyysiä varten jokainen asiakkaan vastaus käytiin yksitellen läpi ja luokiteltiin sisältönsä perusteella eri tavoiteluokkiin. 
Tavoiteluokkia ei ollut etukäteen määritelty, vaan ne muodostettiin aineistolähtöisessä, eksploratiivisessa ja iteratiivisessa prosessissa. Luokkien muodostamisessa ei ollut teoreettista taustaa, ja siinä pyrittiin luokittelua ajatellen mahdollisimman yksinkertaiseen esitystapaan.

Kaksi ensimmäistä kirjoittajaa muodostivat yhdessä ensimmäiset luokat sen perusteella, mitkä asiat näyttivät nousevan usein esiin vastauksissa, ja niin, että samanaikaisesti toteutuisivat seuraavat ehdot: 1) luokat olisivat laadullisesti erilaisia, 2) luokat kattaisivat mahdollisimman suuren osan vastauksista ja 3) luokkien määrä pysyisi mahdollisimman pienenä. Näin päädyttiin muodostamaan seuraavat tavoiteluokat: arkiaskareet, kunto, asumisjärjestelyt, kävely/liikkuminen, lääkitys, mielihyvää tuovat asiat, hoitajien käytös ja sosiaaliset asiat. Tämän jälkeen neljä kirjoittajista pohti vielä yhdessä, pitäisikö luokkia lisätä joillekin teemoille tai jakaa luokkia alaluokkiin. Tämän perusteella kuntoluokasta päätettiin erottaa omaksi luokakseen kivunhallinta. Lisäksi uudeksi luokaksi nostettiin teeman tärkeyden vuoksi turvallisuuden tunne. Yksinäisyyden kokemusta ei nostettu omaksi luokaksi, koska yksinäisyyttä ei nimenomaisesti mainittu juuri missään vastauksessa. Asiakkaiden tavoiteluokkia muodostettiin yhteensä 13, koska lopuissa vastauksissa ei esiintynyt selkeitä toistuvia teemoja, jotka olisivat antaneet syyn muodostaa uutta kategoriaa.

Luokkaan "oudot/kummalliset" sijoitettiin vain yksittäisiä vastauksia, jotka vaikuttivat enemmän hoitajien virheellisiltä kirjauksilta kuin vastaukselta tavoitekysymykseen. Ryhmän "muut" osuus jäi noin kahteen prosenttiin kaikista vastauksista, mikä on merkki luokittelun hyvästä kattavuudesta. Luokat ja niiden jakauma on esitetty taulukossa 2. Arkiaskareiden luokkaan sisällytettiin kaikki sellaiset tavoitteet, jotka liittyivät joka päivä tai usein toistuviin kodin tai arkielämän pyörittämiseen liittyviin asioihin, kuten siivous, kahvinkeitto tai vaatehuolto. Kuntoluokkaan sijoitettiin laajasti ajatellen kaikki fyysiseen toimintakykyyn ja somaattiseen terveyteen liittyvät tavoitteet, kuten jalan tai ihon paraneminen, toimintakyvyn säilyminen mahdollisimman pitkään tai kunnon säilyminen. Asumisjärjestelyitä koskeviin tavoitteisiin sisältyi selkeä toive asuinpaikasta, kuten asuminen mahdollisimman pitkään kotona tai nykyisessä yksikössä. Kävely/ liikkuminen-luokan tavoitteissa oli selvästi mainittu kävely, ulkoilu tai muu liikkuminen. Lääkitysluokka puolestaan sisältää tavoitteet, joissa mainittiin lääkkeisiin liittyvät asiat missä tahansa muodossa. Mielihyvää tuovat asiat -luokkaan sisällytettiin toiveet erilaisista harrastuksista, nautintoaineista (kahvi, suklaa) tai yleisesti hyvästä mielestä. Sosiaalisten asioiden luokkaan kuuluvat toiveet omaisten vierailuista, mielenkiintoisesta seurasta tai sosiaalisista aktiviteeteista yksikön sisällä tai sen ulkopuolella. Turvallisuuden tunne -luokkaan sijoitettiin kaikki sellaiset tavoitteet, joissa selkeästi mainittiin turvallisuus. Hoitajien käytös -luokkaan sijoittuivat toiveet, jotka koskivat hoitajien toimintaa, käytänteitä tai ajankäyttöä. Kivunhallinnan luokka kattaa tavoitteet, joissa oli mainittu mitä tahansa kivun kokemiseen liittyvää. Luokkaan muut kuuluvat kaikki sellaiset tavoitteet, jotka eivät sopineet edellä mainittuihin luokkiin.

Kaikki vastaukset jaettiin kahden kirjoittajan toimesta vielä kolmeen luokkaan eli asiakkaan omiin vastauksiin, epäselviin vastauksiin ja hoitajien muotoilemiin vastauksiin. Arvioitsijoiden yksimielisyyttä tässä luokittelussa arvioitiin Cohenin kappa -tunnusluvulla, erikseen kotihoidon ja ympärivuorokautisen hoidon lomakkeiden vastauksille. Laskennassa käytettiin lineaarisesti painotettua kappaa, jolloin lähellä toisiaan olevat vastaukset saivat suuremman painon kuin kaukana toisistaan olevat vastaukset. 


\section{Tulokset}

\section{Asiakkaiden taustatietojen tarkastelua}

Kuten taulukosta 1 nähdään, naisia oli selvästi miehiä enemmän niin kotihoidon (69 \%) kuin ympärivuorokautisen $(72 \%)$ hoidon lomakkeella arvioiduista asiakkaista. Valtaosalla asiakkaista oli kirjattu vain yksi vastaus, mutta ympärivuorokautisen hoidon lomakkeella arvioiduista noin 17 prosentilla oli vähintään kaksi kirjattua vastausta. Kuntien, hoitoyksiköiden ja organisaatioiden määrän perusteella asiakkaat eivät keskittyneet maantieteellisesti suppealle alueelle. Ympärivuorokautisen hoidon lomakkeella arvioidut asiakkaat olivat arkitoiminnoista suoriutumisen (ADL) ja kognition (CPS) perusteella toimintakyvyltään kes- kimäärin selkeästi heikompia kuin kotihoidon lomakkeella arvioidut asiakkaat.

\section{Asiakkaiden asettamat tavoitteet}

Ympärivuorokautisen hoidon lomakkeella arvioiduista asiakkaista 31 prosenttia ja kotihoidon lomakkeella arvioiduista asiakkaista 15 prosenttia ei ilmaissut tai antanut kysyttäessä yhtään tavoitetta (taulukko 2). Ympärivuorokautisen hoidon lomakkeella arvioiduilla asiakkailla tavoitteet jakautuivat tasaisesti eri luokkiin, mutta kuntoon (15\%), mielihyvää tuoviin asioihin (13\%) tai liikkumiseen (12\%) liittyvät tavoitteet olivat yleisimpiä. Kotihoidon lomakkeella arvioiduilla sen sijaan arkiaskareiden sujuminen (24\%), kunnon paraneminen tai ylläpitäminen $(22 \%)$ ja asumisjärjestelyt $(19 \%)$ olivat muita tavoitteita yleisempiä.

Taulukko 2. Asiakkaiden asettamat tavoitteet.

\begin{tabular}{lll}
\hline & $\begin{array}{l}\text { Kotihoidon } \\
\text { välineellä } \\
\text { arvioidut asiakkaat }\end{array}$ & $\begin{array}{l}\text { Ympärivuorokautisen } \\
\text { hoidon välineellä } \\
\text { arvioidut asiakkaat }\end{array}$ \\
\cline { 2 - 3 } & $\mathrm{n}(\%)$ & $\mathrm{n}(\%)$ \\
\hline Ei tavoitteita / ei ilmaise tavoitteita & $218(14.8)$ & $197(30.8)$ \\
Kunto & $357(24.2)$ & $44(6.9)$ \\
Asumisjärjestelyt & $321(21.8)$ & $93(14.5)$ \\
Kävely/liikkuminen & $286(19.4)$ & $43(6.7)$ \\
Lääkitys & $162(11.0)$ & $79(12.3)$ \\
Mielihyvää tuovat asiat & $123(8.3)$ & $1(0.2)$ \\
Sosiaaliset asiat & $70(4.8)$ & $82(12.8)$ \\
Turvallisuuden tunne & $70(4.8)$ & $71(11.1)$ \\
Hoitajien käytös & $55(3.7)$ & $11(1.7)$ \\
Kivunhallinta & $47(3.2)$ & $66(10.3)$ \\
Muut & $46(3.1)$ & $19(3.0)$ \\
Oudot/kummalliset & $31(2.1)$ & $15(2.3)$ \\
\hline
\end{tabular}

Samalla tavoitteiden luokituksella pystyttiin kuvaamaan kattavasti sekä kotihoidon että ympärivuorokautisen hoidon asiakkaiden ta- voitteita. Esimerkkejä eri luokkiin kuuluvista tavoitteista on nähtävissä taulukossa 3. 
Taulukko 3. Esimerkkejä asiakkaiden asettamista tavoitteista.

\begin{tabular}{|c|c|c|}
\hline & $\begin{array}{l}\text { Kotihoidon } \\
\text { välineellä } \\
\text { arvioidut asiakkaat }\end{array}$ & $\begin{array}{l}\text { Ympärivuorokautisen } \\
\text { hoidon välineellä } \\
\text { arvioidut asiakkaat }\end{array}$ \\
\hline Arkiaskareet & $\begin{array}{l}\text { Roskien vienti rollaattorilla, } \\
\text { kun tulee kuivat kelit }\end{array}$ & Kun saisi keittää kahvia \\
\hline Hoitajien käytös & $\begin{array}{l}\text { Kuunnellaan asiakkaan } \\
\text { mielipidettä }\end{array}$ & $\begin{array}{l}\text { Toivoo hoitajien käyvän } \\
\text { useammin }\end{array}$ \\
\hline Kunto & $\begin{array}{l}\text { Toivoo saavansa kuntonsa } \\
\text { yleensä ottaen paremmaksi }\end{array}$ & Nykyisen kunnon säilyminen \\
\hline Kävely/liikkuminen & $\begin{array}{l}\text { Asiakkaan toiveena kyky liikkua } \\
\text { ilman rollaattoria }\end{array}$ & $\begin{array}{l}\text { Toivoo voivansa liikkua aiempaa } \\
\text { enemmän }\end{array}$ \\
\hline Sosiaaliset asiat & $\begin{array}{l}\text { Toivoo enemmän aikaa } \\
\text { keskusteluun }\end{array}$ & $\begin{array}{l}\text { Virkeämmän seuran } \\
\text { toteuttaminen }\end{array}$ \\
\hline Mielihyvää tuovat asiat & $\begin{array}{l}\text { Toivoo saavansa tilata herkkuja } \\
\text { ja limsaa kauppapalvelusta }\end{array}$ & $\begin{array}{l}\text { Haluaisi kyetä vielä tekemään } \\
\text { käsitöitä }\end{array}$ \\
\hline Asumisjärjestelyt & $\begin{array}{l}\text { Haluaa asua mahdollisimman } \\
\text { pitkään kotona }\end{array}$ & $\begin{array}{l}\text { Haluaisi muuttaa takaisin omaan } \\
\text { kotiin }\end{array}$ \\
\hline Kivunhallinta & $\begin{array}{l}\text { Toivoo kipujen, erityisesti } \\
\text { käsivarsien kivun, helpottavan }\end{array}$ & $\begin{array}{l}\text { Toivoo ettei olisi kipuja eikä } \\
\text { tarvitsisi kärsiä }\end{array}$ \\
\hline Lääkitys & $\begin{array}{l}\text { Toivoo saavansa lääkehoitoon } \\
\text { liittyvää apua }\end{array}$ & $\begin{array}{l}\text { Toivoo saavansa lääkettä } \\
\text { säännöllisesti }\end{array}$ \\
\hline Turvallisuuden tunne & $\begin{array}{l}\text { Haluaa kotihoidon olevan } \\
\text { päivittäisenä turvana }\end{array}$ & Että on turvallinen olo \\
\hline Muut & $\begin{array}{l}\text { Haluaa päästä jo pois, } \\
\text { voimat loppu }\end{array}$ & $\begin{array}{l}\text { Että hoitajat lukisivat päivän } \\
\text { lehteä }\end{array}$ \\
\hline Oudot/kummalliset & $\begin{array}{l}\text { Ei ole aiemmissa arvioissa } \\
\text { ilmaissut tavoitteita }\end{array}$ & Ei muutoksia \\
\hline
\end{tabular}

Huom. Taulukon esimerkit ovat muokkaamattomia hoitajin tallentamia vastauksia arviointitilanteessa.

Heikentyneen kognition yhteys vastausten määrään

Taulukossa 4 on esitetty asiakkaan kognitiivisen suoriutumisen yhteys tämän antamien vastausten määrään. Sekä kotihoidon että ympärivuorokautisen hoidon lomakkeilla annet- tujen tavoitteita sisältävien vastausten märä laski voimakkaasti kognition heikentyessä. Huomionarvoista on kuitenkin, että niistäkin asiakkaista, joilla oli merkittävästi heikentynyt kognitio, lähes joka kolmas oli ilmaissut joitakin tavoitteita. 
Taulukko 4. Asiakkaiden kognitio ja asiakkaan tavoitteita koskevaan kysymykseen annettujen vastausten määrä.

\begin{tabular}{llll}
\hline & CPS 0-1 & CPS 2-3 & CPS 4-6 \\
\cline { 2 - 4 } & $\mathrm{n}(\%)$ & $\mathrm{n}(\%)$ & $\mathrm{n}(\%)$ \\
\hline Kotihoidon välineellä arvioidut asiakkaat & & & \\
Ei tavoitteita / ei ilmaise tavoitteita & $44(9.7)$ & $124(21.4)$ & $50(71.4)$ \\
1 tavoitteita sisältävä vastaus & $277(61.3)$ & $332(57.3)$ & $16(22.9)$ \\
Vähintään 2 tavoitteita sisältävää vastausta & $175(29.0)$ & $123(21.2)$ & $4(5.7)$ \\
$\begin{array}{l}\text { Ympärivuorokautisen hoidon välineellä } \\
\text { arvioidut asiakkaat }\end{array}$ & & & \\
Ei tavoitteita / ei ilmaise tavoitteita & $13(13.0)$ & $98(35.1)$ & $86(66.2)$ \\
$\begin{array}{l}1 \text { tavoitteita sisältävä vastaus } \\
\text { Vähintään 2 tavoitteita sisältävää vastausta }\end{array}$ & $58(58.0)$ & $135(48.4)$ & $33(25.4)$ \\
\hline
\end{tabular}

CPS = Cognitive Performance Scale, pistemäärä o-1 = enintään lievästi heikentynyt kognitio, 2-3= kohtalaisesti heikentynyt kognitio, 4-6 = merkittävästi heikentynyt kognitio.

Olivatko tavoitteet todella asiakkaiden omia tavoitteita?

Tavoitteita läpikäydessä vaikutti muun muassa kieliasun perusteella selvältä, että arvioijalle annetusta ohjeistuksesta huolimatta jotkin kirjatuista tavoitteista eivät olleet asiakkaan omia vaan hoitohenkilökunnan märitttelemiä. Esimerkiksi yksi kirjattu tavoite oli tällainen: "Sosiaalinen tk: Kannustetaan osallistumaan yhteisiin tuokioihin, muiden kanssa seurustelu." Ilmiön laajuuden selvittämiseksi kaksi kirjoittajaa luokitteli toisistaan riippumattomasti kaikki tavoitteet kolmeen luokkaan: asiakkaan asettamiin omiin tavoitteisiin, hoitohenkilökunnan asettamiin tavoitteisiin ja epävarmoihin tavoitteisiin (joita oli vaikea luokitella, koska ne eivät kuuluneet selvästi kumpaankaan edellisistä). Toinen arvioitsija luokitteli hoitajien määrittelemiksi tavoitteiksi 29 prosenttia vastauksista ja toinen 36 prosenttia.

Esimerkkejä edellä mainituista kolmesta luokasta (molemmat arvioitsijat samaa mieltä tavoitteen luokasta) on taulukossa 5. Taulukossa esitettyjä tavoitteita ei ole muokattu mitenkään. Vaikuttaakin siltä, että joissakin tapauksissa hoitaja on kirjannut asiakkaan tavoitteen selkeästi niin, että asiakkaan ääni kuuluu sanojen välistä, kun taas joissakin tapauksissa hoitaja on kirjannut tavoitteen niin, että asiakkaan oma ääni ei ole kuultavissa. Kotihoidon lomakkeen vastauksissa painotettu arvioitsijoiden yksimielisyyttä kuvaava kappa-tunnusluku oli 0.70 ja ympärivuorokautisen hoidon lomakkeen vastauksissa 0.81 . Tuloksen perusteella yksimielisyys oli ympärivuorokautisen lomakkeen vastauksissa erittäin hyvä ja kotihoidon lomakkeen vastauksissa hyvä. Hoitohenkilökunnan tavoitteen pystyi siis erottamaan hyvin asiakkaan omasta tavoitteesta, joskin epävarmuutta jäi jonkin verran. Näin ollen rutiininomainen vastausten erottelu datan perusteella ei ole suositeltavaa, mikäli tähdätään virheettömään luokitteluun. 
Taulukko 5. Esimerkkejä asiakkaan ja hoitajan määrittelemistä tavoitteista.

\begin{tabular}{lll}
\hline & $\begin{array}{l}\text { Kotihoidon välineellä arvioidut } \\
\text { asiakkaat }\end{array}$ & $\begin{array}{l}\text { Ympärivuorokautisen hoidon } \\
\text { välineellä arvioidut asiakkaat }\end{array}$ \\
\hline Asiakkaan asettama tavoite & $\begin{array}{l}\text { Asukas toivoisi saavansa jalkansa } \\
\text { parempaan kuntoon }\end{array}$ & Haluan tulla terveeksi \\
$\begin{array}{l}\text { Epäselvää, kumman asettama } \\
\text { tai määrittelemä tavoite } \\
\text { Hoitajan määrittelemä tavoite }\end{array}$ & $\begin{array}{l}\text { Turvallinen lääkehoito } \\
\text { Asiakkaan motivointi vuoteesta } \\
\text { ylösnousuun sekä fyysisen } \\
\text { toimintakyvyn ylläpitäminen }\end{array}$ & Virikkeellisyys päivisin \\
\hline
\end{tabular}

\section{Pohdinta}

Jokainen asiakas on yksilö, ja asiakkaan ääni kuuluu täysin vain silloin, kun asiakkaan tavoite omalle hoidolleen kirjataan juuri siinä muodossa kuin kukin asiakas on sen esittänyt. Hoitajan ja asiakkaan vuorovaikutuksessa nämä yksilölliset tavoitteet ovat tärkeä työkalu. Kokonaiskuvan hahmottamiseksi on kuitenkin hyödyllistä ja arvokasta muodostaa näistä yksilöllisistä tavoitteista tässä tutkimuksessa esitetyn mukainen luokittelu. Näin saatavaa tietoa voidaan hyödyntää esimerkiksi johtamisessa, kuntatasolla tai päättäjätason keskusteluissa, joissa yleensä vaaditaan tiivistä esitysmuotoa ja suunnitellaan yleisiä toimintalinjoja. Jos esimerkiksi jonkin yksikön asiakkaat toivovat kivunlievitystä huomattavasti useammin kuin muissa yksiköissä, asiaa on syytä tarkastella lähemmin.

Tässä tutkimuksessa otettiin askel kohti tiivistä luokittelua, jota voidaan kehittää ja muokata kulloistenkin tarpeiden pohjalta. Tulosten perusteella kymmenen ylemmän tason luokkaa riitti luokittelemaan suurimman osan asiakkaiden tavoitteista karkealla tasolla. Enemmistö tavoitteista oli selkeitä ja tarkkarajaisia, kuten "haluaisin asua kotona mahdollisimman pitkään" tai "haluaisin että jalat toimivat mahdollisimman pitkään". On kuitenkin vaikea arvioida tavoitteiden realistisuutta tai kohtuullisuutta huomioimatta asiakkaan toimintakykyä ja tarkkoja olosuhteita, joissa tavoitteet on esitet- ty. Kokonaisuutena tavoitteet näyttivät ylläpitävän toivoa.

Kognition tasosta riippumatta merkittävä osa asiakkaista pystyi ilmaisemaan omia tavoitteitaan. On myös syytä huomioida, että asiakas voi kertoa tavoitteitaan myös varsinaisen säännöllisen RAI-arvioinnin ulkopuolella. Näiden tavoitteiden kuulemiseen ja tunnistamiseen olisi hyvä olla jatkuva valmius, ja RAItietoihin voidaan tehdä pieni osittainen tavoitepäivitys koska tahansa. Kotihoidon lomakkeella arvioidut asiakkaat mainitsivat yleisimmin toiveen siitä, että elämä ja arki sujuisi tutussa ympäristössä mahdollisimman pitkään. Ympärivuorokautisen hoidon lomakkeella arvioitujen asiakkaiden tavoitteiden kirjo oli laajempi, mutta kunnon pysyminen hyvänä ja nautintoa tuovien asioiden kokeminen nousivat jonkin verran muita enemmän esiin.

Merkillepantavaa oli se, että arviolta noin kolmannes tavoitteista vaikutti olevan enemmän hoitohenkilökunnan asettamia tavoitteita asiakkaalle kuin asiakkaan itsensä omin sanoin esittämiä. Tämä ilmiö on syytä ottaa huomioon, kun hoitajia jatkossa koulutetaan asiakkaan omien tavoitteiden kirjaamisesta. RAI-välineet ovat käytännöiltään joustavia, vaikka kaikki kysymykset kattava kokonaisarviointi tehdäänkin säännöllisesti. Kokonaisarvioinnin lisäksi RAItiedot voidaan myös päivittää tarvittaessa osittain. Osittaisarviointeihin kokonaisarviointien välillä myös kannustetaan. Muutenkin RAIn lähtökohtana on asiakaslähtöisyys eli asiakkaan 
tuominen mukaan arvioinnin eri vaiheisiin kunnioittamalla asiakkaan näkökulmaa asioihin. Kiireinen hoitotyön arki saattaa kuitenkin hidastaa RAIn käytäntöjen omaksumista osaksi omaa työtapaa.

Tutkimuksen viesti on, että asiakkaiden tavoitteita pitää ja kannattaa kysyä. Tästä on todennäköistä hyötyä kahdella tasolla. Hoitajan ja asiakkaan vuorovaikutuksessa saadaan systemaattisesti kuuluviin ja näkyviin asiakkaan ääni, ja siten parannetaan itsemääräämisoikeuden toteutumista. Johtamis- ja palveluiden järjestäjätasolla pystytään seuraamaan asiakkaiden asettamien tavoitteiden jakaumaa ja myös vertailemaan sitä vastaaviin muihin toimijoihin. Tässä tutkimuksessa ei seurattu asiakkaan tavoitteiden toteutumista tai niiden vaikutusta eri käytäntöihin. Se on yksi mahdollinen jatkotutkimuksen aihe. Aiemmissa tutkimuksissa on havaittu, että asiakkaan toiveet huomioiva työtapa saattaa parantaa asiakkaiden tyytyväisyyttä hoitoon ja koettua elämänlaatua sekä vähentää hoitohenkilöstön ahdistusta ja edistää henkilöstön tiimityöskentelyä (McCormack \& McCance 2006; Bölenius ym. 2017). Nämä myönteiset seuraukset voivat puolestaan parantaa turvallisuutta ja hoitotuloksia sekä vähentää muiden palvelujen tarvetta, minkä ansiosta voidaan saada aikaan säästöjä hoitokustannuksissa (Edvardsson ym. 2017; Bunn ym. 2018).

Suomessa esimerkiksi kuntoutustyössä on jo jonkin aikaa käytetty Goal Attainment Scaling -menetelmää (GAS), jonka avulla määritellään asiakkaan omat tavoitteet kuntoutukselle hyvän kuntoutumiskäytännön edistämiseksi (Sipari ym. 2019). Nyt RAIvälineiden avulla asiakkaan omia tavoitteita pyritään saamaan olennaiseksi osaksi asiakkaan hoidon ja palveluiden suunnittelua ja niiden toteutumisen arviointia. Tämä tutkimus osoitti, että useimmiten asiakkaat asettavat selkeitä tavoitteita. Tavoitteet auttavat hoidon suunnittelua yhteistyössä asiakkaiden kanssa, mihin asiakaslähtöisessä työtavassa juuri pyritäänkin. On luultavaa, että oma kirjattu selkeä tavoite motivoi asiakasta toimimaan ja ponnistele- maan sitä kohti ja luo tunteen kuulluksi tulemisesta (Pirhonen 2017). Tavoitteiden toteutumista ja toteutumisen mahdollisia vaikutuksia asiakkaisiin voidaan seurata jatkotutkimuksissa. Pitkittäistutkimusasetelma vaaditaan, jos halutaan saada tietoa tavoitteiden toteutumisen tai toteutumattomuuden yhteydestä asiakkaan hyvinvointiin tai siitä, onko tavoitteiden toteutumiseksi tehty yksikössä aktiivisesti työtä.

On tärkeää pohtia, miten tieto asiakkaan tavoitteista voi ohjata kohti hyvää hoitokäytäntöä. Yksilötyössä ja iäkkäiden asiakkaiden kohtaamisessa tavoitteiden sanatarkka sisältö on hyödyllistä tietoa, sillä se voi tuoda esiin tärkeitä yksityiskohtia asiakkaan arjesta ja näkemyksistä. Organisaatiotasolla sanatarkka sisältö ei luultavasti ole kovin hyödyllistä, mutta tieto siitä, onko asiakkailla tavoitteita ylipäätään, sekä tavoitteiden jakautuminen eri tavoiteluokkiin on todennäköisesti johtamisen ja palvelutarjonnan kannalta hyödyllistä (Kahanpää 2019). Omat tavoitteet antavat asiakkaalle äänen, jonka kuuluminen läpi palvelujärjestelmän edistää osallisuutta, jota myös vanhuspalvelulaki edellyttää.

\section{Tutkimuksen heikkoudet ja vahvuudet}

Tutkimuksen vahvuutena voidaan pitää kattavia asiakasarviointeja monesta eri yksiköstä. Näin tavoitteista saatiin kattavampi kuva kuin keskittymällä vain muutamaan kuntaan tai organisaatioon. Avovastaukset mahdollistivat asiakkaiden tavoitteiden laajan tarkastelun, jolloin voitiin varmistua siitä, että tavoiteluokat todella kuvasivat asiakkaiden tavoitteita riittävällä tarkkuudella. Eräs heikkous oli se, että tarkkaa vastausprosenttia ei käytännössä pystytty määrittelemään, koska puuttuva vastaus saattoi merkitä useaa eri asiaa: esimerkiksi sitä, että uusi kysymys oli otettu käyttöön yksikössä vähitellen, yksikön käyttämä RAI-ohjelmiston versio ei vielä tukenut kysymystä, yksikön johdossa oli päätetty olla vastaamatta kysymykseen, asiakas ei halunnut, pystynyt, ehtinyt tai osannut vastata kysymykseen tai hoitaja itse 
halusi olla vastaamatta tai ei ehtinyt perehtyä riittävästi uuteen RAI-kysymykseen vastatakseen. Lisäksi annettua ohjeistusta ei kaikilta osin noudatettu, vaan yhdellä rivillä oli useita tavoitteita sisältäviä kompleksitavoitteita, ja hoitajien asettamat ja asiakkaiden asettamat tavoitteet sekoittuivat ajoittain keskenään. Tämä aiheutti jonkin verran tulkinnan epävarmuutta.

Koska asiakkaan tavoitteiden kirjaaminen oli uusi lähestymistapa, hoitajien arviointiosaaminen ja rutiini kyseisen kysymyksen kohdalla saattoi olla vielä puutteellinen, mikä saattoi heijastua tavoitteiden laatuun ja sisältöön. Asiakasryhmät olivat myös heterogeenisiä, sillä kotihoidon lomakkeella vastasi niin kotona kuin palveluasumisessa asuvia ja ympärivuorokautisen hoidon lomakkeella niin vanhainkodeissa kuin erilaisessa palveluasumisessa asuvia. Tässä tutkimuksessa ei vielä selvitetty, olivatko kirjatut asiakkaiden asettamat tavoitteet vaikuttaneet yksikköjen ja hoitajien toimintaan, vaikka tähän tavoitteiden kirjaamisella pyritään.

Yhteenvetona voidaan todeta, että vanhuspalveluissa olevat asiakkaat pystyvät asettamaan hoidolleen selkeitä tavoitteita. Myös merkittävä osa niistä asiakkaista, joilla oli heikentynyt kognitio, pystyi asettamaan tavoitteita. Asiakkaiden tavoitteiden tulisi osaltaan ohjata hoito- ja palvelusuunnitelmien laadintaa ja

\section{Kirjallisuus}

Bunn F, Goodman C, Russell B, Wilson P, Manthorpe J Rait ym. Supporting shared decision making for older people with multiple health and social care needs: a realist synthesis. BMC Geriatr 2018;18(1):e165. https://doi.org/10.1186/s12877-018-0853-9

Bölenius K, Lämås K, Sandman P, Edvardsson D. Effects and meanings of a person-centred and health-promoting intervention in home care services-a study protocol of a non-randomised controlled trial. BMC Geriatr 2017;17(1):e57. https://doi.org/10.1186/s12877-017-0445-0

Coulter A, Entwistle VA, Eccles A, Ryan S, Shepperd S, Perera R. Personalised care planning niiden päivittämistä, jolloin niillä on vaikutusta asiakkaiden osallisuuden kokemuksiin palveluissa. On perusteltua, että asiakkaan tavoitteet kysytään ja kirjataan avokysymyksen avulla, koska tällöin asiakkaan ääni näkyy vastauksissa parhaiten. Toisaalta erilaiset valmiit tavoiteluokat, kuten kivunlievitys, turvallisuus ja arkiaskareet, voisivat helpottaa asiakkaan vastaamista ja hoitajien kirjaamista sekä etenkin kertyneen aineiston analysointia. Toisaalta uhkana on se, että valmiit tavoiteluokat ohjaisivat vastauksia liikaa, jolloin asiakkaan ääni ei pääsisi aidosti esiin. Voidaan myös ajatella, että asiakkaan tavoitteita kysyttäisiin vaihtelevasti eri kerroilla: joskus avokysymyksellä ja joskus valmiiden tavoiteluokkien avulla. Pääpainon pitää kuitenkin pysyä siinä, että asiakas tulee varmasti kuulluksi ja että hänen itsemääräämisoikeutensa toteutuu. Asiakkaan tavoitteista tarvitaan lisätutkimusta laajemmilla aineistoilla, ja jatkossa pitäisi tutkia, kuinka hyvin kirjatut tavoitteet todella ovat toteutuneet.

\section{Yhteydenotto:}

Kim Josefsson, FT, erikoistutkija

Terveyden ja hyvinvoinnin laitos (THL)

Hyvinvointi-osasto

Iäkkäät, vammaiset ja toimintakyky -yksikkö kim.josefsson@thl.fi

for adults with chronic or long-term health conditions. Cochrane Database Syst Rev 2015(3):CD010523. https://doi.org/10.1002/14651858.cd010523. pub2

Coulter A, Oldham J. Person-centred care: what is it and how do we get there? Future Hosp J 2016;3(2):114-6. https://dx.doi.org/10.7861\%2Ffuturehosp.3-2-114

Deci EL, Ryan, RM. The "what" and "why" of goal pursuits: human needs and the self-determination of behavior. Psychol Inq 2000;11(4):227-68. https://doi.org/10.1207/S15327965PLI1104_01 
Eaton S, Roberts S, Turner B. Delivering person centred care in long term conditions. BMJ 2015; 350:h181. https://doi.org/10.1136/bmj.h181

Edvardsson D, Watt E, Pearce F. Patient experiences of caring and person-centredness are associated with perceived nursing care quality. J Adv Nurs 2017;73(1):217-27. https://doi.org/10.1111/jan.13105

Elliott J, McNeil H, Ashbourne J, Huson K, Boscart V, Stolee P. Engaging older adults in health care decision-making: a realist synthesis. Patient 2016;9(5):383-93. https://doi.org/10.1007/s40271-016-0168-x

Freund AM, Riediger M. Goals as building blocks of personality and development in adulthood. In: Mroczek DK, Little TD, ed. Handbook of personality development. Mahwah, NJ: Laurence Erlbaum Associates, 2006:353-72.

Garms-Homolová V, Notthoff N, Declercq A, van der Roest HG, Onder G, Jónsson P, van Hout $H$. Social and functional health of home care clients with different levels of cognitive impairments. Aging Ment Health 2017;21(1):18-23. https://doi.org/10.1080/13607863.2016.1247426

Howard EP, Schreiber R, Morris JN, Russotto A, Flashner-Fineman S. COLLAGE 360: a model of person-centered care to promote health among older adults. J Ageing Res Healthc 2016;1(1):21-30. https://doi.org/10.14302/issn.2474-7785.jarh16-1123

InterRAI consortium. 2020. Internet: https://www. interrai.org/ (viitattu 28.3.2021).

Isola A, Kaartinen H, Leemann L, Lääperi R, Schneider T, Valtari S ym. Mitä osallisuus on? Osallisuuden viitekehystä rakentamassa. Helsinki: Terveyden ja hyvinvoinnin laitos, 2017.

Jansson A, Karisto A, Pitkälä K. Loneliness in assisted living facilities: an exploration of the group process. Scand J Occup Ther 2021;28(5): 354-65. https://doi.org/10.1080/11038128.2019.1690043

Kahanpää A. Koettu hoidon laatu: asukkaan, läheisen ja henkilökunnan näkemyksiä asukkaan hoidon laadusta ikääntyneiden ympärivuorokautisessa pitkäaikaishoidossa. Tampere: Tampereen yliopisto, 2019.

Kogan AC, Wilber K, Mosqueda L. Person-centered care for older adults with chronic conditions and functional impairment: a systematic literature review J Am Geriatr Soc 2016;64(1):e1-7. https://doi.org/10.1111/jgs.13873
Koivisto J, Isola A, Lyytikäinen M. Osallisuus kuuluu kaikille: Innokylän innovaatiokatsaus. Helsinki: Terveyden ja hyvinvoinnin laitos, 2018.

Lewis-Barned N. Shared decision making and support for self-management: a rationale for change. Future Hosp J 2016;3(2):117-20. https://dx.doi.org/10.7861\%2Ffuturehosp.3-2-117

Little BR. Prompt and circumstance: the generative contexts of personal projects analysis. Mahwah, NJ: Lawrence Erlbaum Associates Publishers, 2007:3-49.

McCormack B, McCance TV. Development of a framework for person-centred nursing. J Adv Nurs 2006;56(5):472-9.

https://doi.org/10.1111/j.1365-

2648.2006.04042.x

Moore L, Britten N, Lydahl D, Naldemirci Ö, Elam M, Wolf A. Barriers and facilitators to the implementation of person-centred care in different healthcare contexts. Scand J Caring Sci 2017;31(4):662-73.

https://doi.org/10.1111/scs.12376

Noro A, Karppanen S. Ikäihmisten kotihoidon ja kaikenikäisten omaishoidon uudistus 2016-2018. Tuloksia ja toimintamalleja. Helsinki: Sosiaalija terveysministeriö, 2019.

Onder G, Carpenter I, Finne-Soveri H, Gindin J, Frijters D, Henrard JC ym. Assessment of nursing home residents in Europe: the Services and Health for Elderly in Long TERm care (SHELTER) study. BMC Health Serv Res 2012;12(1):e5.

https://doi.org/10.1186/1472-6963-12-5

Pirhonen J. Good human life in assisted living for older people: what the residents are able to do and be. Tampere: Tampere University Press, 2017.

Sipari S, Vänskä N, Lehtonen K, Pihlava J. GAS-menetelmän käyttö Kelan sopeutumisvalmennuskursseilla. Kuntoutujan omat tavoitteet -tutkimus. Helsinki: Kela, 2019.

Sosiaali- ja terveysministeriö. Laatusuositus hyvän ikääntymisen turvaamiseksi ja palvelujen parantamiseksi 2017-2019. Helsinki: Sosiaali- ja terveysministeriö, 2017. Internet:

https://stm.fi/julkaisu?pubid=URN:ISBN:978-952-00-3960-8 (viitattu 28.3.2021).

Sosiaali- ja terveysministeriö \& Suomen Kuntaliitto. Laatusuositus hyvän ikääntymisen turvaamiseksi ja palvelujen parantamiseksi 2020-2023: tavoitteena ikäystävällinen Suomi. Helsinki: Sosi- 
aali- ja terveysministeriö, 2020. Internet: https:// julkaisut.valtioneuvosto.fi/handle/10024/162455 (viitattu 28.3.2021).

Terveyden ja hyvinvoinnin laitos. Tietoa RAI-järjestelmästä. 2019. Internet: https://thl.fi/fi/web/ ikaantyminen/palvelutarpeiden-arviointi-rai-jar- jestelmalla/tietoa-rai-jarjestelmasta (viitattu 28.3.2021).

Terveyden ja hyvinvoinnin laitos. Verkkokoulu. 2021. Internet: https://verkkokoulut.thl.fi/login/index. php (viitattu 28.3.2021). 